\title{
Peningkatan Aktivitas dan Hasil Belajar Siswa melalui Model Kooperatif Tipe Team Game Tournament pada Mata Pelajaran Fisika Kelas X di SMK Dharma Bakti Lubuk Alung
}

\author{
Nelfi Erlinda \\ Prodi Pendidikan Fisika, STKIP Yayasan Dharma Bakti; Email: nelfi_erlinda@yahoo.com
}

Diterima: 1 Maret 2017. Disetujui: 22 Mei 2017. Dipublikasikan: Juni 2017

\begin{abstract}
The aim of this study is to describe the level of physical activity and student learning outcomes through the implementation of cooperative models TGT X grade students at SMK Dharma Bakti Lubuk Alung. The research conducted is a Class Action Research (PTK). The subjects were X.1 grade students of SMK Dharma Bakti Lubuk Alung. Data collection instrument consists of two parts, namely; the observation sheet is to determine the activity of students in learning and daily test is to determine student mastery of the material that has been studied. Data analysis technique used is the percentage technique, the method of graphs, descriptive statistics and analysis. Based on the results of data analysis that has been done can be put forward two main result of this study, 1) Implementation of cooperative models TGT can increase the activity and learning outcomes Physical Science class students of SMK Dharma Bakti Lubuk Alung, 2) the students learning outcomes have exceeded KKM 80.00 is set, this means learning outcomes increased by $60.99 \%$ from the average student's learning outcomes before the study.
\end{abstract}

\begin{abstract}
Abstrak
Tujuan dari penelitian ini adalah untuk mendeskripsikan tingkat aktivitas fisik dan hasil belajar siswa melalui penerapan model koperasi siswa kelas X TGT X di SMK Dharma Bakti Lubuk Alung. Penelitian yang dilakukan adalah Class Action Research (PTK). Subjek adalah siswa kelas X.1 SMK Dharma Bakti Lubuk Alung. Alat pengumpulan data terdiri dari dua bagian, yaitu lembar observasi untuk mengetahui aktivitas siswa dalam pembelajaran dan tes harian untuk mengetahui penguasaan siswa terhadap materi yang telah dipelajari. Teknik analisis data yang digunakan adalah teknik persentase, metode grafik, statistik deskriptif dan analisis. Berdasarkan hasil analisis data yang telah dilakukan dapat diajukan dua hasil utama penelitian ini, 1) Penerapan model kooperatif TGT dapat meningkatkan aktivitas dan hasil pembelajaran siswa kelas I Ilmu Pengetahuan Fisika SMK Dharma Bakti Lubuk Alung, 2) siswa Hasil pembelajaran telah melampaui KKM 80,00, artinya hasil belajar meningkat sebesar 60,99\% dari rata-rata hasil belajar siswa sebelum penelitian.
\end{abstract}

Kata kunci: kooperaif, TGT, aktivitas siswa, hasil belajar.

(C) 2017 URPI, FTK UIN Raden Intan Lampung

\section{PENDAHULUAN}

Kegiatan belajar yang dilaksanakan pada suatu sekolah merupakan faktor yang mempengaruhi kualitas sekolah tersebut (Muzakar, 2014). Kualitas sekolah dipengaruhi oleh beberapa faktor antara lain: kemampuan guru, ketersediaan sarana dan prasarana, kemampuan siswa, dukungan dari sekolah, pemilihan metode pembelajaran dan sebagainya (Farida, Murniati, \& Khairuddin, 2014). Faktor-faktor tersebut akan saling mempengaruhi antara yang satu dengan yang lainnya.

Model pembelajaran perlu mendapat perhatian dari berbagai pihak (Gani, 2015). Strategi pembelajaran yang digunakan di 
sekolah akan berhubungan langsung dengan keberhasilan proses pembelajaran siswa. Penggunaan model pembelajaran yang tidak sesuai dengan keadaan suatu sekolah akan berdampak pada keberhasilan siswa memahami konsep yang dipelajari (Juleha, Khuzaemah, \& Cahyani, 2014). Hal ini akan terlihat dari hasil belajar siswa tidak dapat memenuhi KKM yang ditetapkan sekolah. Pemilihan model pembelajaran di sekolah harus mampu meningkatkan proses pembelajaran siswa, sehingga hasil belajar siswa dapat memenuhi KKM yang ditetapkan sekolah (Purwandari, 2015).

Berdasarkan analisis penyelidikan literatur menganjurkan bahwa dalam pembelajaran, siswa lebih banyak bekerja dari pada mendengar. Mereka harus membaca, menulis, berdiskusi, ikut serta dalam pemecahan masalah (Cahyanti, 2015). Suatu hal yang sangat penting dalam hal ini adalah siswa terlibat secara aktif dalam pembelajaran, menggunakan keahlian berpikir lebih tinggi dalam mengerjakan tugas seperti analisis, sintesis dan evaluasi.

Model pembelajaran yang dilaksanakan di sekolah-sekolah seharusnya mampu meningkatkan aktivitas dan penguasaan siswa terhadap materi yang diajarkan serta memberikan kontribusi yang berarti terhadap hasil belajar siswa (Megawati, 2011), namun kualitas yang ada dilapangan terjadi sebaliknya. Penguasaan terhadap materi serta hasil belajar Fisika siswa kelas X.1 di SMK Dharma Bakti Lubuk Alung masih rendah. Hal ini terlihat dari nilai rata-rata ulangan harian I siswa kelas X.1 adalah 56,78. Nilai ulangan harian ini belum mencapai KKM yang ditetapkan yaitu 80. Ini membuktikan proses pembelajaran yang dilaksanakan selama ini belum efektif.

Berdasarkan observasi peneliti, aktivitas belajar Fisika siswa pada kelas X.1 di SMK Dharma Bakti Lubuk Alung masih rendah dan pembelajaran terpusat pada guru. Berbagai gejala yang tampak pada proses pembelajaran seperti: siswa kurang mau bertanya, enggan menjawab pertanyaan guru, kurang mampu menjelaskan, kurang bersemangat dalam belajar, pasif dalam diskusi. Hal ini menyebabkan prosen pembelajaran menjadi kurang semarak karena siswa kurang aktif. Akibatnya, siswa cepat bosan, kurang serius dalam belajar. Pelaksanaan pembelajaran seperti ini berdampak terhadap rendahnya hasil belajar fisika, sehingga materi dirasakan sulit dan hasil belajar kurang maksimal.

Upaya untuk mengatasi permasalahan ini perlu dipikirkan dan dilaksanakan. Salah satu alternatif yang diperkirakan mampu mengatasi persoalan tersebut adalah meningkatkan proses pembelajaran fisika dengan menerapkan model pembelajaran kooperatif tipe Team Game Tournament (TGT) (Salam, Hossain, \& Rahman, 2015).

Beberapa keuntungan yang terdapat dalam penerapan model kooperatif tipe TGT yaitu (Pangestuti, Mistianah, Corebima, \& Zubaidah, 2015), 1) Kelompok mempunyai buah pikiran yang lebih kaya dibandingkan dengan yang dimiliki perorangan, 2) Anggota kelompok akan termotivasi dengan kehadiran anggota kelompok lain, 3) Anggota yang pemalu akan bebas mengemukakan pikirannya dalam kelompok kecil, 4) Dapat menghasilkan keputusan yang lebih baik, 5) Partisipasi dalam diskusi dapat meningkatkan pemahaman diri sendiri maupun orang lain (Frianto, Eko Soetjipto, \& Amirudin, 2016).

Berdasarkan keuntungan tersebut penerapan model kooperatif tipe TGT diperkirakan mampu meningkatkan proses pembelajaran sehingga hasil belajar siswa dapat ditingkatkan (Sudarmi, Wayan Suwatra, \& Made Suarjana, 2014). Alasan ini yang membuat peneliti tertarik untuk menerapkan model kooperatif tipe TGT dalam pembelajaran fisika. Penelitian ini bertujuan untuk mendeskripsikan tingkat aktivitas dan hasil belajar fisika siswa melalui penerapan model kooperatif tipe TGT pada siswa kelas X.1 di SMK Dharma Bakti Lubuk Alung. 


\section{METODE PENELITIAN}

Penelitian yang dilaksanakan termasuk kepada Penelitian Tindakan Kelas (PTK). Tindakan diberikan oleh guru dan dengan arahan dari guru yang dilakukan oleh siswa. Subjek dalam penelitian ini adalah kelas X.1 di SMK Dharma Bakti Lubuk Alung tahun ajaran 2014/2015. Penelitian ini dilaksanakan dalam 2 siklus. masing-masing siklus melalui 4 tahapan yaitu perencanaan (Planning). Tindakan (action), pengamatan (observation), umpan balik (reflection). Satu siklus dilakukan 2 kali pertemuan, 1 kali pertemuan alokasi waktunya 2x40 menit.

Menurut Permendiknas nomor 41 tahun 2007 tentang standar proses, dalam pelaksanaan kegiatan inti menggunakan metode yang disesuaikan dengan karakteristik peserta didik dan mata pelajaran yang meliputi proses eksplorasi, eleborasi dan konfirmasi yang termuat dalam skenario pembelajaran seperti pada Tabel 1 .

Tabel 1. Skenario Pembelajaran Model Kooperatiff Tipe TGT

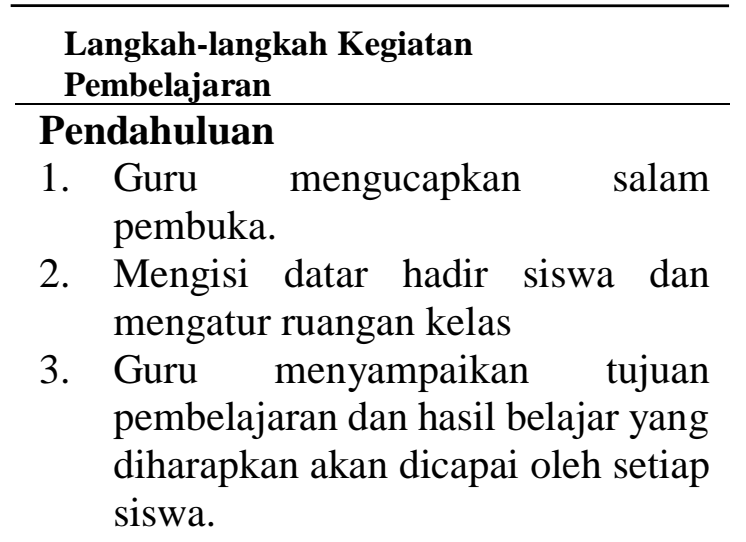

Apersepsi/Motivasi

4. Guna menanyakan kepada siswa tentang pengalaman sehari-hari yang berkaitan dengan energi dan listrik.

5. Guru menjelaskan secara singkat model pembelajaran kooperatif tipe
TGT yang digunakan dalam
pembelajaran

\section{Kegiatan Inti}

Eksplorasi

1. Guru menyampaikan materi pelajaran secara singkat ${ }^{(a)}$.

2. Guru meminta siswa membentuk kelompok, yang setiap kelompok terdiri dari $4-5$ siswa ${ }^{(b)}$.

3. Guru meminta setiap kelompok mengerjakan LKS dan menjelaskan secara singkat serta memberi bimbingan cara mengerjakan LKS

4. Guru senantiasa bertanya untuk mengetahui sampai sejauh mana pemahaman siswa tentang materi yang telah disampaikan ${ }^{(c)}$.

\section{Elaborasi}

5. Guru meminta siswa melakukan tournament yaitu setiap kelompok mewakilkan anggotanya untuk ke meja tournament. Siswa diminta untuk menjawab soal-soal yang tersedia di meja tournament secara bergantian, salah satu dari mereka sebagai pembaca soal dan satu lagi sebagai pembaca kunci jawaban, yang dapat menjawab pertanyaan dengan benar berhak memegang kunci jawabannya, dan mendapat poin $^{(\mathrm{d})}$.

6. Guru mengumumkan dan memberi penghargaan kepada kelompok yang menang ${ }^{(\mathrm{e})}$.

7. Guru meminta siswa mengerjakan soal evaluasi sesuai dengan materi yang sedang dibahas secara individu.

8. Guru meminta siswa mengumpulkan jawaban dari soal evaluasi yang diberikan. 


\section{Konfirmasi}

9. Guru memberikan klariffikasi atau meluruskan permasalahan yang muncul selama pembelajaran berlangsung

10. Jika ada persoalan yang belum mampu dipecahkan siswa, maka guru mengulas kembali materi dan memberikan jawaban yang benar, akan tetapi bilamana jawaban siswa benar, maka guru menegaskan jawaban tersebut.

\section{Penutup}

1. Guru memberikan tugas rumah kepada siswa tentang penyelesaian persamaan linear satu variabel yang ekuivalen.

2. Guru dan siswa bersama-sama menarik kesimpulan tentang materi yang telah dipelajari

3. Guru megucapkan salam penutup.

\section{HASIL DAN PEMBAHASAN}

Setelah mengamati aktivitas dan hasil belajar siswa pada siklus pertama dan menganalisnya, maka dilakukan beberapa revisi terhadap tindakan yang telah dilakukan dan akan diterapkan pada siklus kedua. Analisa dilakukan guna mencari kekurangan dan kebutuhan yang belum dicapai di siklus pertama. Setelah melakukan revisi didapatkan persentase rata-rata aktivitas siswa dalam pembelajaran dan hasil belajar siswa yang berbeda dengan siklus pertama. Terjadi peningkatan antara siklus pertama dan siklus kedua. Secara umum perbedaan hasil siklus kedua dengan siklus pertama terdiri dari dua bagian. Bagian pertama adalah aktivitas siswa dalam pembelajaran. Sementara yang kedua adalah hasil belajar siswa dalam strategi pembelajaran kooperatif.

\section{Perbedaan Aktivitas Siswa}

Perbedaan persentase rata-rata aktivitas siswa pada siklus satu dengan siklus dua diperlihatkan oleh gambar 1.

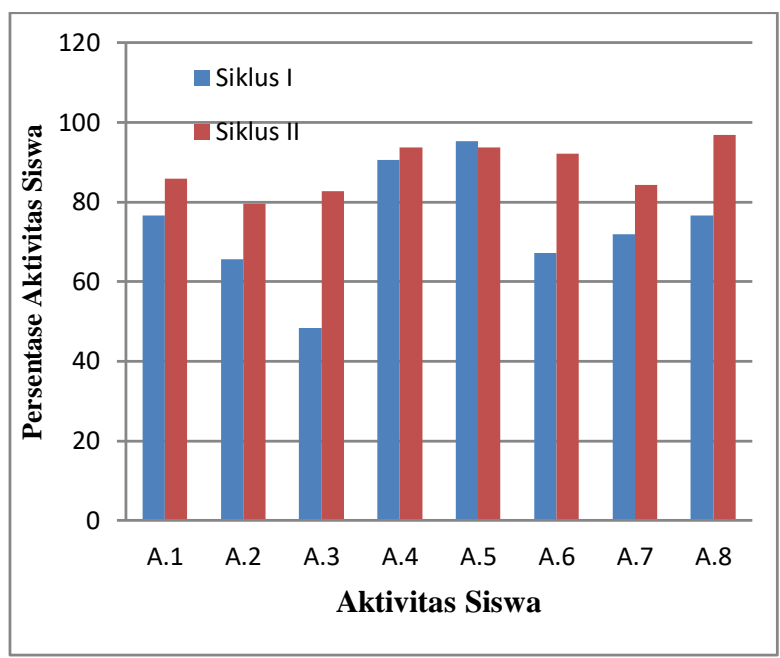

Gambar 1. Perbedaan Persentase Rata-rata Aktivitas Siklus Pertama dan Kedua

Jika dibandingkan siklus dua dengan siklus satu, maka terlihat kenaikan persentase ratarata aktivitas siswa untuk setiap aspek yang diamati kecuali pada aspek mendiskusikan krgiatan belajar siswa terjadi penurunan $1,56 \%$. Kenaikan persentase aktivitas siswa yang emperhatikan penjelasan guru, menjawab pertanyaan guru, bertanya kepada guru, mengerjakan LKS, gembira waktu guru memberikan penghargaan, berpartisipasi mengambil kesimpulan, dan mencatat kesimpulan pelajaran masing-masingnya adalah 9,38\%, 14,07\%, 34,38\%, 3,13\%, $25,00 \%$, $\quad 12,50 \%$, dan $20,31 \%$.

\section{Perbedaan Hasil Belajar Siswa}

Berdasarkan beberapa parameter statistik deskriptif nilai tes kecil dan nilai tes hasil belajar siswa siklus pertama dan siklus kedua dapat ditentukan perbandingan nilai tes kecil siswa dan nilai tes hasil belajar siswa dari kedua siklus. Caranya adalah dengan membandingkan parameter statistik deskriptif 
meliputi, nilai rata-rata, nilai minimum, nilai maksimal, range, dan standar deviasi. Hasil perbandingan parameter statistik deskriptif nilai tes kecil siswa dari kedua siklus ditampilkan pada Gambar 2.

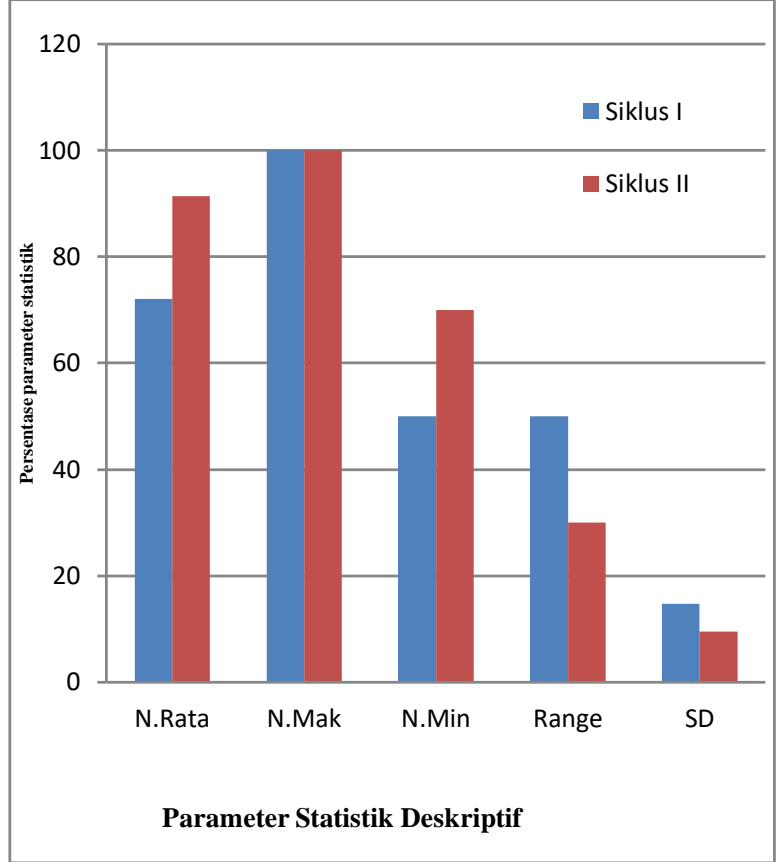

Gambar 2. Perbedaan Nilai Tes Kecil Siswa

Berdasarkan Gambar 2 dapat dikemukakan bahwa adanya peningkatan nilai rata-rata ulangan harian dari siklus pertama. Pada siklus pertama nilai rata-rata ulangan harian adalah 72,03 dan pada siklus kedua adalah 91,41 . Hal ini berarti terjadi peningkatan nilai rata-rata ulangan harian sebesar $19.38 \%$.

Apabila ditinjau perbandingan parameter statistik deskriptif nilai maksimal ulangan harian pada kelas X.1, ternyata tidak terjadi peningkatan ataupun penurunan nilai maksimal ulangan harian, dengan kata lain nilai maksimal ulangan harian siklus pertama sama dengan ulangan harian siklus kedua yaitu sebesar 100. Disisi lain, rata-rata parameter statistik deskriptif nilai minimal ulangan harian siklus kedua lebih tinggi $40 \%$ dari siklus pertama, dimana pada siklus pertama nilai minimal ulangan harian adalah 50, sedangkan pada siklus kedua adalah 70 .

Rata-rata range nilai siklus pertama adalah 50 dan rata range nilai siklus kedua adalah 30 . Ini berarti range nilai siklus kedua lebih kecil $40 \%$ dari range siklus pertama. Berbeda halnya dengan rata-rata standar deviasi siklus pertama dan siklus kedua. Pada siklus pertama ratra-rata standar deviasi adalah 14,73 dan pada siklus kedua adalah 9,54. Hal ini berarti terjadi penurunan rata-rata standar deviasi sebesar $35,23 \%$.

\section{SIMPULAN DAN SARAN}

Berdasarkan hasil analisis data yang telah dilakukan dapat dikemukakan kesimpulan dari penelitian yaitu sebagai berikut:

a. Penerapan model kooperatif tipe TGT dapat meningkatkan aktivitas dan hasil belajar Fisika siswa SMK Dharma Bakti Lubuk Alung. Hal ini terlihat dari peningkatan aktivitas siswa pada 8 aspek yang diamati pada siklus pertama dan siklus kedua.

b. Hasil belajar siswa yang diperoleh pada siklus pertama tergolong rendah dengan nilai rata-rata ulangan harian adalah 72,03. Nilai ini masih berada dibawah KKM yang ditetapkan. Pada siklus kedua nilai ratarata ulangan harian adalah 91,41. Hal ini berarti hasil belajar siswa telah melebihi KKM yang ditetapkan di SMK Dharma Bakti Lubuk Alung.

c. Rata-rata hasil belajar siswa pada penelitian naik sebesar 60,99\% dari ratarata hasil belajar siswa sebelum penelitian.

Beberapa saran yang dapat dikemukakan dari hasil penelitian ini adalah :

1. Kepada peneliti lain untuk dapat mengembangkan penelitian ini diberbagai sekolah tingkat SMP atau sederajat khususnya dan sekolah tingkat SMA atau sederajat pada umumnya

2. Kepada kepala SMK Dharma Bakti Lubuk Alung, agar menjadi pertimbangan untuk 
mengambil kebijakan tentang pembelajaran di SMK Dharma Bakti Lubuk Alung.

\section{DAFTAR PUSTAKA}

Cahyanti, A. E. (2015). Pengembangan Perangkat Pembelajaran Matematika dengan Pendekatan Problem Based Learning untuk Meningkatkan Kemampuan Higher Order Thinking. In Seminar Nasional Matematika Dan Pendidikan Matematika UNY (pp. 8392).

Farida, C. A., Murniati, \& Khairuddin. (2014). Supervisi Pengajaran Oleh Kepala Sekolah untuk Meningkatkan Kinerja Guru di SMP Negeri 12 Banda Aceh. Jurnal Administrasi Pendidikan, 4(2), 133-156.

Frianto, Eko Soetjipto, B., \& Amirudin, A. (2016). The Implementation of Cooperative Learning Model Team Game Tournament and Fan N Pick To Enhance Motivation and Social Studies Learning Outcomes. IOSR Journal Of Humanities And Social Science (IOSRJHSS), 21(5), 74-81.

Gani, A. (2015). Pengaruh Model Pembelajaran dan Persepsi Tentang Matematika Terhadap Minat dan Hasil Belajar Matematika Siswa SMP Negeri Di Kecamatan Salomekko Kabupaten Bone. Jurnal Daya Matematis, 3(3), 337-343.

Juleha, S., Khuzaemah, E., \& Cahyani, D. (2014). Penerapan Strategi Belajar Murder untuk Meningkatkan
Penguasaan Konsep Siswa pada Pembelajaran Biologi Kelas VIII MTs Al-Ikhlas Setupatok Cirebon. Science Educatia, 3(2), 95-109.

Megawati. (2011). Penerapan Model Pembelajaran Explicit Instruction Untuk Meningkatkan Hasil Belajar Siswa pada Mata Pelajaran IPA di Kelas V SDN Ginunggung Tolitoli. Jurnal Kreatif Tadulako, 4(10), 126-141.

Muzakar. (2014). Kinerja Kepala Sekolah dalam Meningkatkan Mutu Lulusan pada Madrasah Tsanawiyah Negeri Meureubo. Jurnal Ilmiah Islam Futura, 4(1), 110-133.

Pangestuti, A. A., Mistianah, Corebima, A., \& Zubaidah, S. (2015). Using ReadingConcept Map-Teams Games Tournament (Remap-TGT) to Improve Reading Interest of Tenth Grade Student of Laboratory Senior High School State University of Malang. American Journal of Educational Research, 3(2), 250-254. https://doi.org/10.12691/education-3-219

Purwandari, N. (2015). Peningkatan Keterampilan Proses dan Hasil Belajar IPA melalui Penerapan Model Pembelajaran Berbasis Proyek pada Siswa Kelas IV SD N 2 Srandakan. Jurnal Pendidikan Gutu Sekolah Dasar, 15(4), 1-10.

Salam, A., Hossain, A., \& Rahman, S. (2015). Effects of using Teams Games Tournaments (TGT) Cooperative Technique for Learning Mathematics in 
Secondary Schools of Bangladesh.

Malaysian Online Journal of

Educational Technology, 3(3), 1-11.

Sudarmi, M. Y., Wayan Suwatra, I., \& Made

Suarjana, I. (2014). Penerapan Model

Pembelajaran Kooperatif Tipe Teams

Games Tournament (TGT) untuk

Meningkatkan Hasil Belajar Pendidikan

Kewarganegaraan. E-Journal MIMBAR

PGSD Universitas Pendidikan Ganesha, 2(1), 1-10. 